\title{
Timing of Strobilurin Fungicide for Control of Top Dieback in Corn
}

\author{
Eric Adee and Stewart Duncan, Department of Agronomy, Kansas State University, Manhattan 66506
}

Accepted for publication 22 May 2017.

\begin{abstract}
Significant yield losses can result from top dieback (TDB) in dent corn (Zea mays L.), which is caused by infection by the fungus Colletotrichum graminicola, which also causes anthracnose. Research on the effectiveness of fungicide application is limited because of the unpredictable nature of the disease. Three field studies were established to assess the timing of fungicide

application for foliar diseases that developed TDB, one in Illinois (2010) and the other two in Kansas (2015 and 2016). Fungicide applications at tasseling and later were effective in reducing the incidence of TDB by over $20 \%$ and increasing yield over $900 \mathrm{~kg} / \mathrm{ha}$, or over 7\%, while earlier applications (V5 to V8) did not reduce TDB nor increase yield compared with the untreated check.
\end{abstract}

Top dieback (TDB) of dent corn (Zea mays L.) is caused by an infection of the upper stalk of the corn plant by the fungus that causes anthracnose, Colletotrichum graminicola (Ces.) G.W. Wils., generally above the ear leaf. Additionally, C. graminicola can infect the corn plant early in the season, causing foliar lesions, and/or stay dormant in the plant until stress conditions cause the infection to result in stalk rot and/or TDB symptoms (Bergstrom and Nicholson 1999). Yield losses to anthracnose TDB in 2012 in North America were estimated at $13 \%$ (Mueller and Wise 2012). Infections later in the season under the right environmental conditions have been reported when the infection occurs in the pretassel whorl or on the leaf sheaths (Munkvold 2002). Spores of C. graminicola are dispersed by wind and rain, and infection is favored by warm, humid, and overcast conditions (Bergstrom and Nicholson 1999). The symptoms of TDB can be diagnosed when leaves in the top part of the plant, primarily the flag leaf, start to become reddish-purple, then yellow (Fig. 1), and then necrotic, while the lower leaves around the ear remain green (Bergstrom and Nicholson 1999; Robertson 2007). The formation of black lesions and fungal fruiting bodies on the stalk near and under the leaf sheath confirm the diagnosis and distinguish TDB from other causes of the top of the corn plant dying prematurely (Bergstrom and Nicholson 1999; Robertson 2007).

Management practices to reduce losses to anthracnose in corn include hybrid selection, crop rotation, controlling insect damage, and reducing stress from low fertility and moisture as much as possible (Bergstrom and Nicholson 1999; Jirak-Peterson and Esker 2011). Strobilurin fungicides are effective at controlling the leaf blight phase of anthracnose, primarily in the early growth stages (Wise 2015). However, there is little information on the effectiveness of strobilurins against the TDB phase of anthracnose. Strobilurins applied at tasseling or later reduced TDB, but did not affect yield in a one-year fungicide study conducted by Robertson et al. (2010). Furthermore, reproducing the conditions that result in TDB is difficult, hindering experimentation. Similarly, the authors have observed that repeating the same study for controlling TDB at multiple locations or years has not been very successful, with TDB

Corresponding author: Eric Adee; E-mail: eadee@ksu.edu

(C) 2017 The American Phytopathological Society in only three of nine corn fungicide studies. The results presented in this paper are from these three fungicide timing studies that involved infection with $C$. graminicola causing the TDB symptoms of anthracnose.

\section{Field Experiments}

Fungicide timing application studies on corn that developed TDB symptoms were conducted in 2010 at the University of Illinois' Northwestern Illinois Agricultural Research and Demonstration Center (NWRC), near Monmouth, IL (4056'06.73" N; 9043' 10.85" W), and in 2015 and 2016 at Kansas State University's Kansas River Valley Experiment Field (KRV), near Topeka, KS (3904'36.17" N; $\left.95^{\circ} 46^{\prime} 07.71^{\prime \prime} \mathrm{W}\right)$ (Table 1). The dryland study at NWRC was in corn following soybeans, while the studies at KRV were under sprinkler irrigation in second-year corn. Nitrogen fertilizer was applied at recommended levels at all locations (Table 1). Due to the sandy soils and $254 \mathrm{~mm}$ of rain in May 2015 at KRV, additional $\mathrm{N}$ at $145 \mathrm{~kg} / \mathrm{ha}$ was sidedressed at V5 (five leaves with collars visible; Abendroth et al. 2011), which alleviated some of the $\mathrm{N}$ deficiency symptoms. In all studies, the corn was planted in 76-cm rows: hybrid DeKalb 61-69 (Monsanto, St. Louis, MO) at NWRC and Golden Harvest 11U58-3111 and Golden Harvest G12-J-11-3111 (Syngenta, Research Triangle, NC) at KRV in 2015 and 2016, respectively. DeKalb 61-69 had Cry3Bb1, Golden Harvest G11U58-3111 had MIR162, and G12-J-11-3111 had the Cry1F Bt events for resistance to European corn borer, Ostrinia nubilalis (Hubner). The plots were $3 \mathrm{~m}$ wide (4 rows) by $30 \mathrm{~m}$ long at NWRC and $12 \mathrm{~m}$ long at KRV. The experimental design was randomized complete block with four replications for both studies. Additional crop management details are listed in Table 1. The irrigation scheduling at KRV was assisted by the KanSched2 irrigation scheduling program (Rogers and Alam 2008).

The fungicide treatments were applied with a $\mathrm{CO}_{2}$ backpack sprayer equipped with Spraying Systems TJ 8002VS nozzles (Spraying Systems, Glendale Heights, IL) set on 38-cm spacing on a $1.5-\mathrm{m}$ wide boom at $30 \mathrm{psi}, 29.38$ liters/ha to the middle two rows of a four-row plot. The fungicide applied at NWRC was Headline SC (BASF Corp., Research Triangle Park, NC) at $72 \mathrm{ml} / \mathrm{ha}$. At KRV, Stratego Yld (48 ml/ha), Headline SC (72 ml/ha), Headline AMP (120 ml/ha), Aproach $2.08 \mathrm{SC}(81 \mathrm{ml} / \mathrm{ha})$, and Aproach Prima $(81 \mathrm{ml} / \mathrm{ha})$ were applied in proprietary studies conducted for Bayer CropScience 
(Research Triangle Park, NC) and DuPont Crop Protection (Wilmington, DE) in 2015. In 2016, additional companies were represented, which included BASF (Research Triangle Park, NC), Helm Ag (Hamburg, Germany), and FMC (Philadelphia, PA). Additional fungicides included in the 2016 trials were Preemptor (60 ml/ha), Topguard EQ (72 ml/ha), Fortix (60 ml/ha), Helmstar

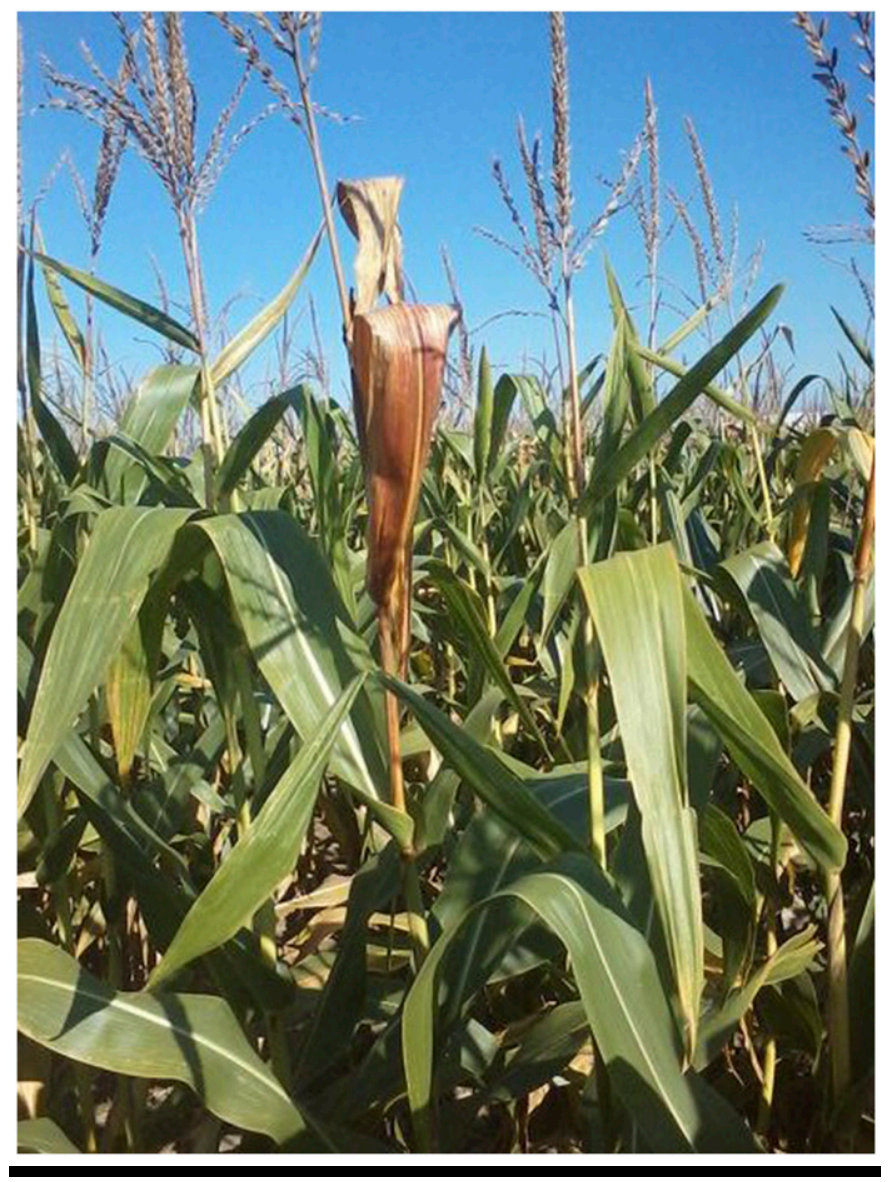

FIGURE 1

Top dieback in dent corn, which is caused by infection by the fungus causing anthracnose. Eric Adee, Kansas River Valley Experiment Field, Topeka, KS, 2015.
Plus (111 ml/ha), Custodia (155 ml/ha), Priaxor (60 ml/ha), and QuiltXcel (126 ml/ha), along with some numbered compounds containing strobilurin and conazole also included. Stratego Yld, Headline AMP, Aproach Prima, Preemptor, ToguardEQ, Helmstar Plus, and QuiltXcel contain conazole in addition to the strobilurin. At KRV, multiple fungicide treatments applied at the same time were grouped for analysis because there were no significant differences in TDB, foliar disease, and yield between strobilurin treatments applied at the same time $(\operatorname{Pr}>\mathrm{F}>0.05)$ (data not shown). The growth stages of the corn at treatment applications were: V5 to 8 (five to eight leaves with collars emerged); tasseling (VT); seven days after tasseling (VT +7 days); and 14 days after tasseling (VT +14 days).

\section{Data Collection and Analysis}

Foliar disease severity was quantified at R5 (dent), evaluating the severity of foliar disease from the ear leaf and above as a percent of the leaf area with symptoms in the middle two rows of each plot. Gray leaf spot (GLS), Cercospora zeae-maydis (Tehon and W.Y. Daniels), was the predominate leaf disease at NWRC, and GLS and common rust, Puccinia sorghi (Schwein.), were present at KRV. Plants with the top two to four leaves with purple or yellow coloration or necrotic, while the lower leaves remained green, occurred in the studies (Fig. 1). Observations of black lesions and fungal fruiting bodies on the stalk near and under the leaf sheath below the lowest leaf that expressed symptoms confirmed that the TDB symptoms were caused by $C$. graminicola. Additionally, the absence of any insect feeding into the stalk, such as European corn borer, showed there was not an additional factor causing TDB. Quantifying the incidence of TDB was accomplished by counting the number of plants exhibiting symptoms in the middle two rows of each plot and converting to a percentage of all plants. At harvest, the tops of many of the plants infected with TDB had lodged or had fallen off the plant, but lodging notes were not taken because there was no lodging of any stalks at the ear or below that impeded harvest. The middle two rows of the plots were harvested for yield with a Kincaid 8XP (Kincaid Mfg., Haven, KS) plot combine equipped with a HarvestMaster High Capacity GrainGage system (Juniper Systems, Logan, UT) at NWRC, and a modified John Deere 3300 combine (Deere Co., Moline, IL) equipped with a HarvestMaster Classic Graingage system at KRV. Yields were calculated from plot

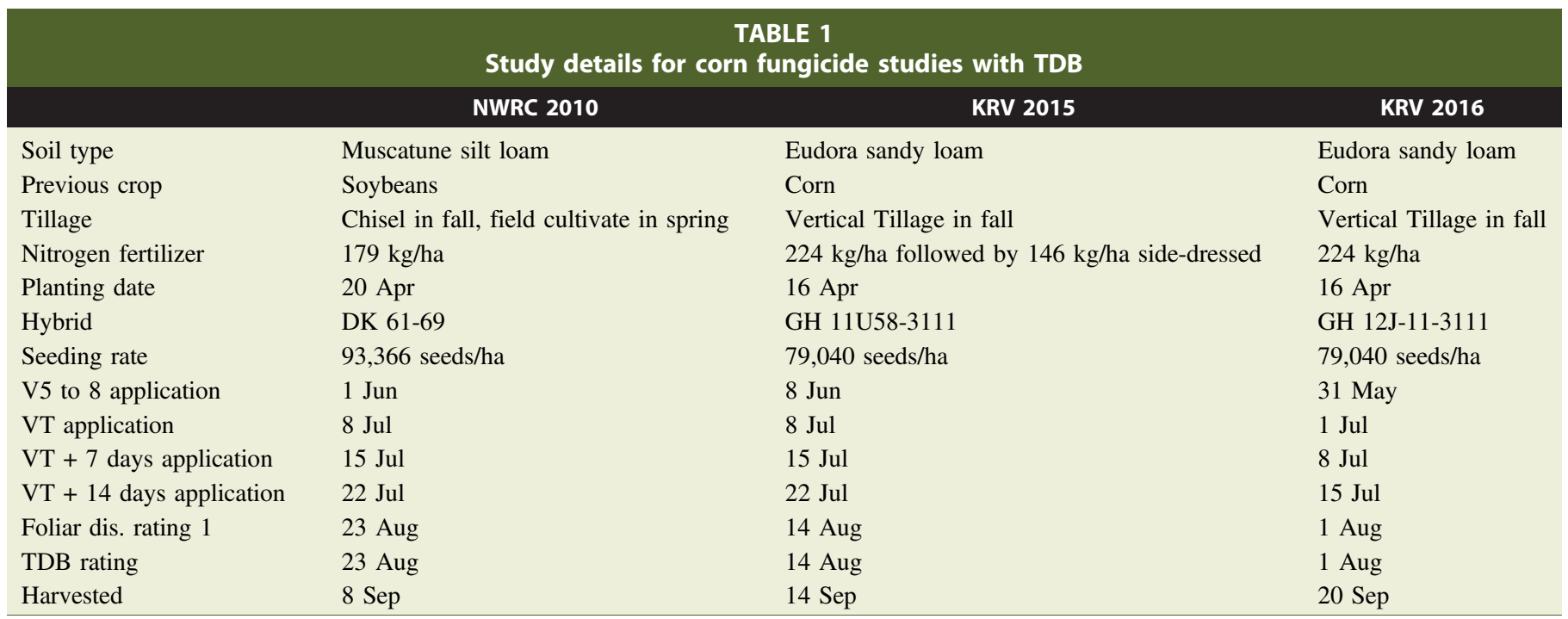


weights adjusted to $155 \mathrm{~g} / \mathrm{kg}$ grain moisture. Return on fungicide investment for an application at different growth stages was calculated by multiplying the average yield increase over the check treatment for the three years of the study by corn price, then subtracting an estimated cost of foliar fungicide and application. A range of corn prices and costs of fungicide application were utilized to include possible value/cost ratios a grower might encounter.

Statistical analysis was conducted using the GLIMMIX procedure in the SAS statistical software (SAS Institute, Inc., Cray, NC). Data were analyzed and presented by location and across locations.

\section{Effect of Fungicide Application on Top Dieback in Corn}

The early-season fungicide application at the V5 to V8 growth stages did not reduce foliar disease or TDB nor increase yield when compared with the untreated check (Tables 2, 3, 4, and 5). As a result, fungicide application did not result in a positive economic return (Table 6). The lack of effectiveness of fungicides against TDB indicates the infection occurred after the V5 to V8 application, and near VT when the environmental conditions were very favorable for the disease.

The foliar application of fungicides to corn at VT or up to 14 days after VT reduced the incidence of TDB to less than half of the incidence in the untreated checks, and resulted in increased grain yield up to $10 \%$ (Tables 2, 3, 4, and 5). The reduction in TDB and foliar leaf disease by the fungicide applications were very similar at all locations (Table 2, 3, and 4), with greater reduction in the diseases with the VT and later timing of fungicide application. Due to the variability within the experiment at KRV in 2015, the effect of timing of fungicide application was not significant for yield (Table 3), but the relationships between treatments were similar to those at NWRC (Table 2). The lower incidence of TDB in 2016 resulted in no difference between yields as well (Table 4). The combined analysis showed differences between timing of fungicide application in yield, reduction of TDB, and foliar disease, with the application at VT or later resulting in greater yields than with the untreated check and less TDB and disease (Table 5).

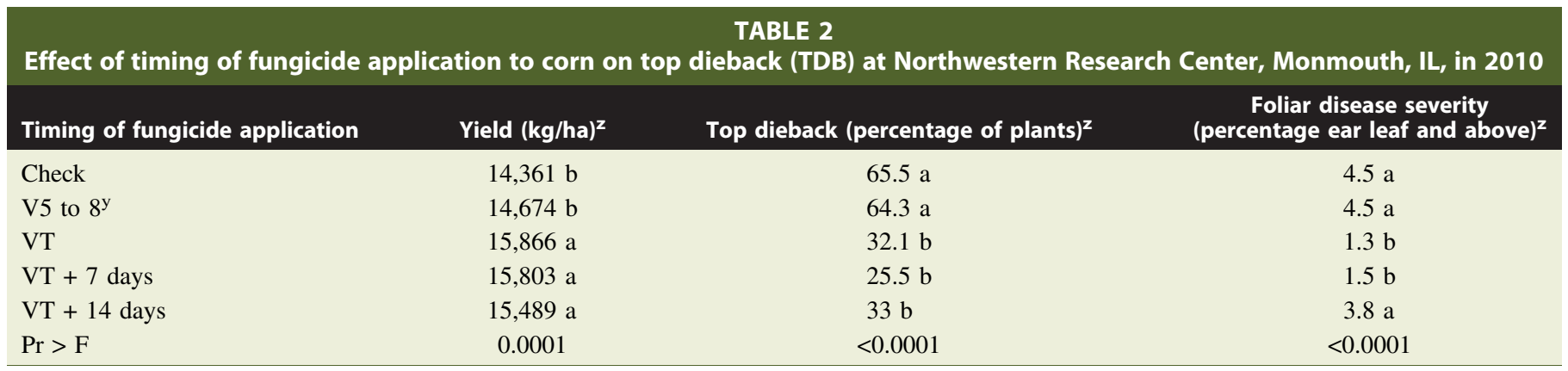

${ }^{\mathrm{y}}$ Corn grow stages: V5 to $8=5$ to 8 leaf collar visible; VT $=$ tasseling.

${ }^{\mathrm{z}}$ Means followed by the same letter within a column are not significantly different at $\operatorname{Pr}>0.05$.

\begin{tabular}{lccc}
\multicolumn{4}{c}{ Effect of timing of fungicide application to corn on top dieback (TDB) at Kansas River Valley, Topeka, KS, in 2015 } \\
Timing of fungicide application & Yield (kg/ha) & Top dieback (percentage of plants) & $\begin{array}{c}\text { Toliar disease severity } \\
\text { (percentage ear leaf and above) }\end{array}$ \\
Check & 8,027 & $37.0 \mathrm{a}$ & $6.2 \mathrm{a}$ \\
V5 to $8^{\mathrm{y}}$ & 8,027 & $33.1 \mathrm{a}$ & $3.3 \mathrm{~b}$ \\
VT & 8,968 & $12.6 \mathrm{~b}$ & $2.3 \mathrm{~b}$ \\
VT + 7 days & 8,779 & $14.9 \mathrm{~b}$ & $2.3 \mathrm{~b}$ \\
VT + 14 days & 9,030 & $18.4 \mathrm{~b}$ & $1.7 \mathrm{~b}$ \\
Pr $>$ F & 0.50 & $<0.0001$ & $<0.0001$ \\
\hline
\end{tabular}

${ }^{\mathrm{y}}$ Corn grow stages: V5 to $8=5$ to 8 leaf collar visible; VT $=$ tasseling.

${ }^{\mathrm{z}}$ Means followed by the same letter within a column are not significantly different at $\operatorname{Pr}>0.05$.

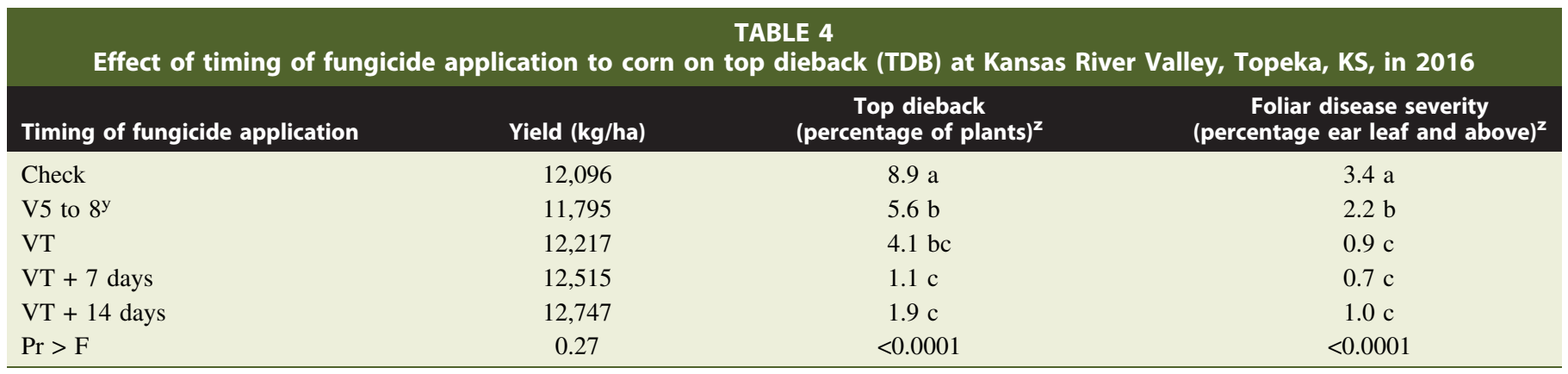

${ }^{\mathrm{y}}$ Corn grow stages: V5 to $8=5$ to 8 leaf collar visible; VT $=$ tasseling.

${ }^{\mathrm{z}}$ Means followed by the same letter within a column are not significantly different at $\operatorname{Pr}>0.05$. 
Foliar disease level, due to GLS and common rust, was reduced from $5 \%$ in the untreated checks, to $3 \%$ or less (Tables 2, 3, 4, and 5 ), but at a level of severity that had little impact on yield (Adee et al. 2005; Wise 2010; Wise and Mueller 2011). Applying a strobilurin fungicide up to 2 weeks after VT also resulted in a positive return on investment of the foliar fungicide application (Table 6). The rate of return for the investment in fungicide application can be influenced by ratio between the value of corn and the cost of the fungicide application. The effect of the timing of strobilurin fungicides on TDB agrees with the results from a study conducted in Iowa (Robertson et al. 2010), where TDB was reduced by the VT or later application of fungicides.

The yield potential was much lower at KRV in 2015, averaging $8,278 \mathrm{~kg} / \mathrm{ha}$, compared with 14,925 and $12,274 \mathrm{~kg} / \mathrm{ha}$, respectively, at NWRC and KRV in 2016. Excessive rainfall in May caused a loss of $\mathrm{N}$ in the KRV soil for which sidedressed $\mathrm{N}$ could not fully compensate. Additionally, the incidence of TDB in the check treatment was $65 \%$ at NWRC compared with $37 \%$ at KRV in 2015 and $8.9 \%$ at KRV in 2016. However, the response of TDB to the fungicide applications was very similar at all locations (Tables 2 and 3). While there were many differences between the three locations, the period of several days of rain and/overcast days just prior to or at VT was a common factor (Figs. 2 and 3) linking the occurrence of TDB.

Anthracnose is favored by warm, wet, and overcast conditions (Figs. 2 and 3) (Bergstrom and Nicholson 1999). The onset of TDB in these studies is probably attributable to several days of rain and overcast conditions around tasseling. Irrigation was probably not a very significant factor since most irrigation occurs when the solar radiation is relatively high (Figs. 3 and 4). At KRV in 2015, corn reached VT in the period of July 6 to 10 under overcast conditions which resulted in below-average solar radiation recorded. For the week around VT in 2015 and 2016, the average solar radiation was 15.8 and $17.6 \mathrm{~mJ} / \mathrm{m}^{2}$, respectively (Fig. 3), compared with the VT week average of $26.4,23.7$, and $22.5 \mathrm{~mJ} / \mathrm{m}^{2}$ for 2012,2013 , and 2014, respectively (Fig. 4), with several days over $30 \mathrm{~mJ} / \mathrm{m}^{2}$ (Weather Data Library 2016). No TDB was observed in the corn fungicide trials at KRV in 2012, 2013, and 2014. Corresponding with the increased solar radiation for the years with no TDB, there was very little or no rain around VT. No anthracnose lesions were observed at any location at the V5 to V8 growth stages.

Additional factors that favored TDB development at KRV were crop rotation, tillage, and possible $\mathrm{N}$ stress (Bergstrom and Nicholson 1999; Jirak-Peterson and Esker 2011). The studies at KRV were planted into cornstalks that had been vertical tilled with a TurboMax tool (Great Plains Mfg., Salina, KS) in the fall, leaving ample corn residue on the soil surface to serve as an inoculum source. Additionally, the $\mathrm{N}$ deficiency experienced early in the 2015 season and into the growing season could have been an additional stress factor that could have made the corn more susceptible to TDB. The conditions at NWRC were favorable for high yield potential, and there were no other factors other than the warm and humid weather conditions that increased the risk of TDB.

\section{Practical Applications}

Relative to TDB, the positive benefit to fungicide application for up to two weeks after VT demonstrates a relatively wide window of application time that will still result in a positive return on investment for fungicide application. Delays to fungicide application at VT could be attributed to weather or scheduling a commercial applicator. A two-week window gives growers some flexibility

\begin{tabular}{|c|c|c|c|}
\hline \multicolumn{4}{|c|}{$\begin{array}{l}\text { TABLE } 5 \\
\text { Combined data on effect of timing of fungicide application to corn on top dieback (TDB) at Northwestern Research Center } \\
\text { (NWRC), IL, in 2010, and Kansas River Valley (KRV), KS, in } 2015 \text { and } 2016\end{array}$} \\
\hline Timing of fungicide application & Yield $(\mathrm{kg} / \mathrm{ha})^{\mathbf{z}}$ & $\begin{array}{c}\text { Top dieback } \\
\text { (percentage of plants) }\end{array}$ & $\begin{array}{c}\text { Foliar disease severity } \\
\text { (percentage ear leaf and above) }\end{array}$ \\
\hline Check & $11,502 \mathrm{~b}$ & $37.1 \mathrm{a}$ & $4.5 \mathrm{a}$ \\
\hline V5 to $8^{y}$ & $11,569 \mathrm{~b}$ & $34.6 \mathrm{a}$ & $3.2 \mathrm{~b}$ \\
\hline $\mathrm{VT}+14$ days & 12,415 a & $17.8 \mathrm{~b}$ & $2.0 \mathrm{c}$ \\
\hline $\operatorname{Pr}>\mathrm{F}$ & 0.008 & $<0.0001$ & $<0.0001$ \\
\hline
\end{tabular}

${ }^{\text {y }}$ Corn grow stages: V5 to $8=5$ to 8 leaf collar visible; VT= tasseling.

${ }^{\mathrm{z}}$ Means followed by the same letter within a column are not significantly different at $\operatorname{Pr}>0.05$.

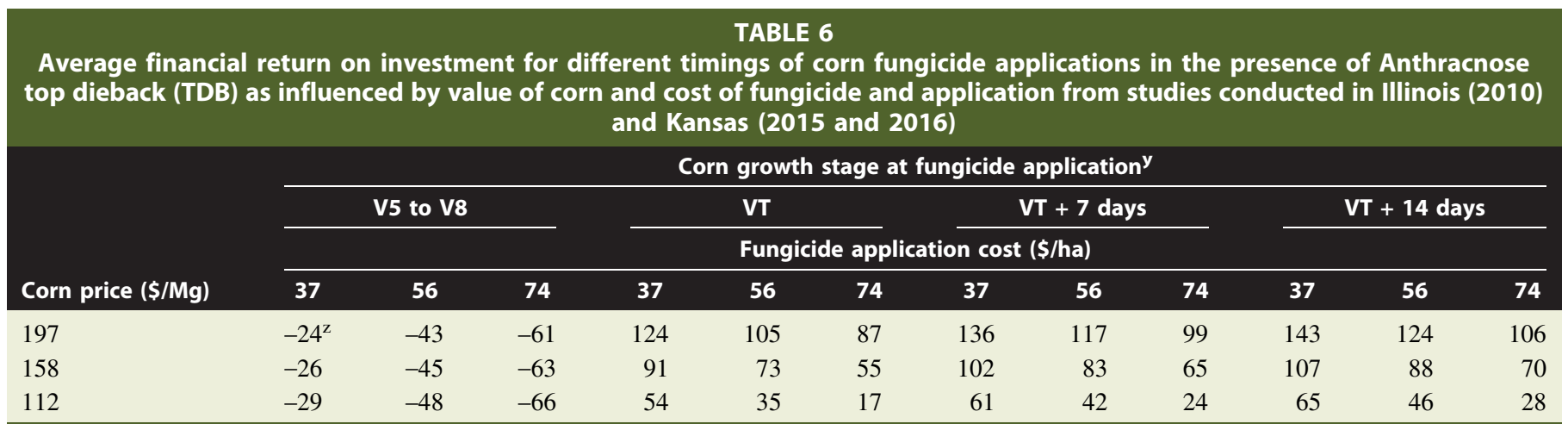

${ }^{\mathrm{y}}$ Corn grow stages: V5 to $8=5$ to 8 leaf collar visible; VT $=$ tasseling.

${ }^{\mathrm{z}}$ Financial return on investment $=$ corn yield increase over check treatment $\times$ value of grain - cost of fungicide and application. 
when faced with potential delays. With foliar fungal diseases, such as GLS and rust, the observation of the symptoms on the lower leaves can be an early indicator that a fungicide application could be warranted if the environmental conditions are favorable for development of disease to progress up through the crop canopy.

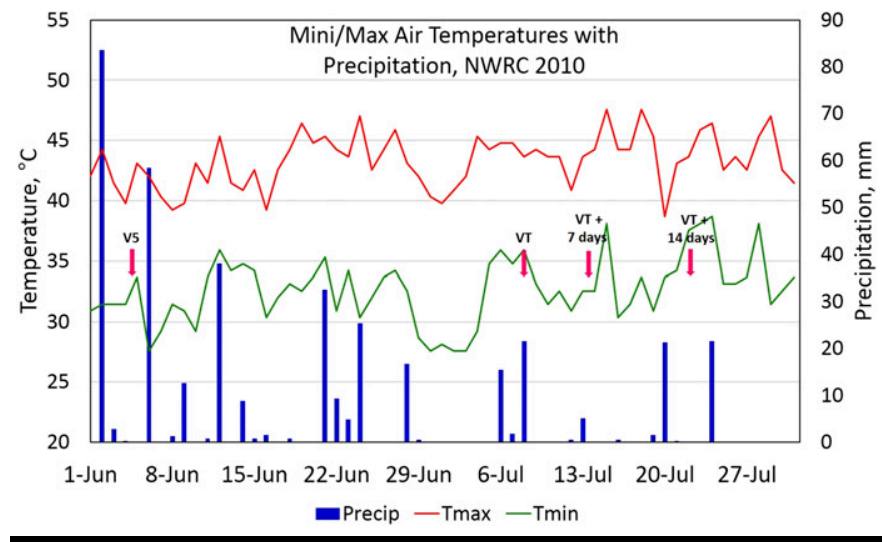

FIGURE 2

Rainfall and temperature data from University of Illinois' Northwestern Illinois Agricultural Research and Demonstration Research Center, Monmouth, IL, for June and July 2010 (National Climate Data Center 2016).
However, with TDB, there may be no early symptoms to alert a grower to a potential problem. A key factor in determining if TDB will be an issue is periods of rainy/overcast conditions just prior to and at VT.

Confirming that fungicides containing strobilurin are effective in reducing TDB and increasing yield of corn could be a significant factor in reducing yield losses to TDB. The difficulty will be in predicting when the environmental conditions are most conducive for TDB. If other foliar fungal diseases are at the threshold to apply a fungicide at VT, then there could be the added benefit of control of TDB. However, if the foliar disease level is below the threshold at VT, it may be more difficult to guarantee a positive return for the investment in the fungicide application. Much more attention should be paid to the timing of overcast periods and rainfall/ irrigation events in coordination with VT. Additionally, better understanding of the hybrid, crop rotation, and/or tillage interaction with rainfall at VT will help improve the success rate of a fungicide application in improving yield in the event that TDB is expressed.

\section{Summary}

These data have demonstrated the effectiveness of strobilurin fungicides in reducing the yield loss to TDB in corn. Additionally, there is a relatively wide window, up to two weeks after VT, for fungicide application that can result in an increase in corn yield and

\section{Solar Radiation and Irrigation/Rainfall VT Fungicide July 7}

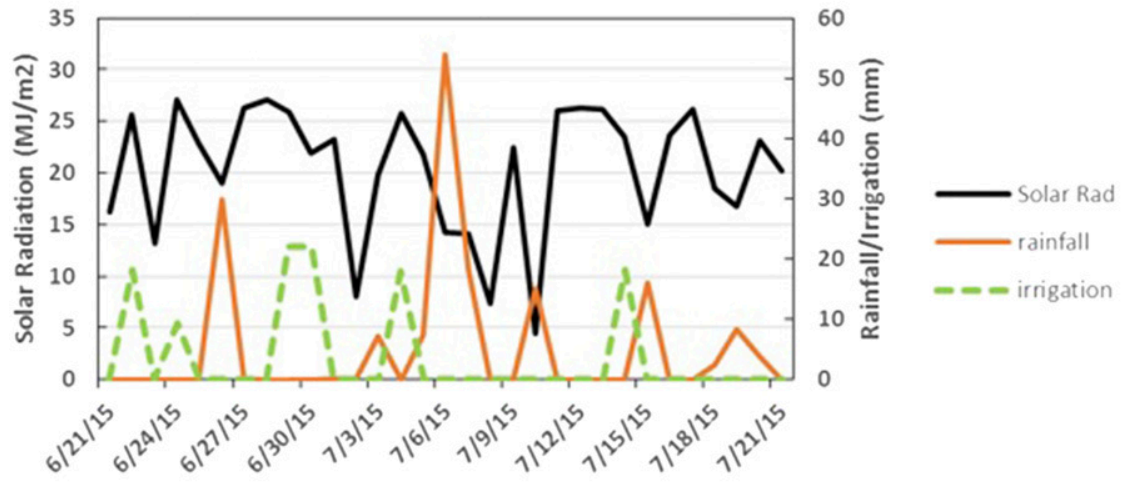

\section{Solar Radiation and Rainfall/Irrigation \\ VT Fungicide July 1}

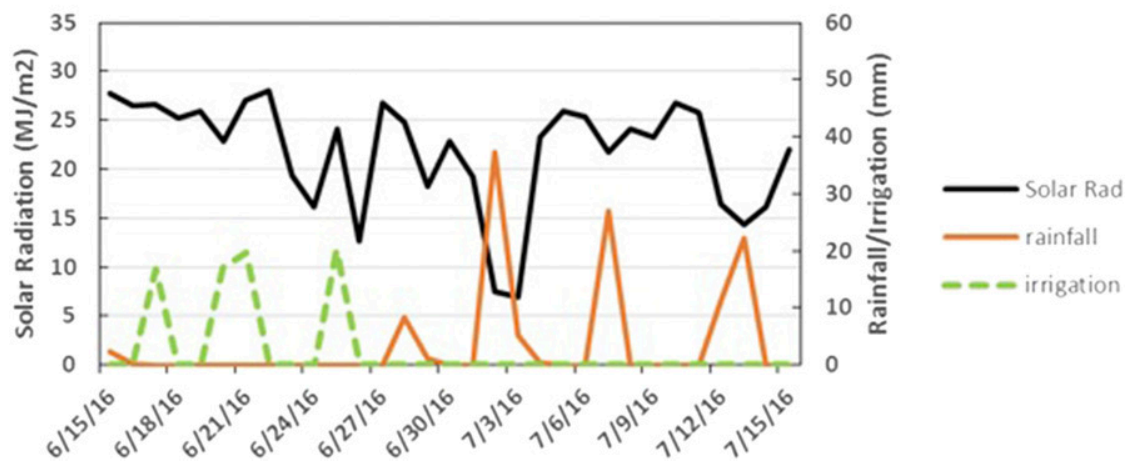

FIGURE 3

Rainfall, solar radiation, and irrigation in years with top dieback of corn at Kansas River Valley Experiment Field. Kansas State University Weather Data Library, 2015 and 2016. 
VT Fungicide July 3

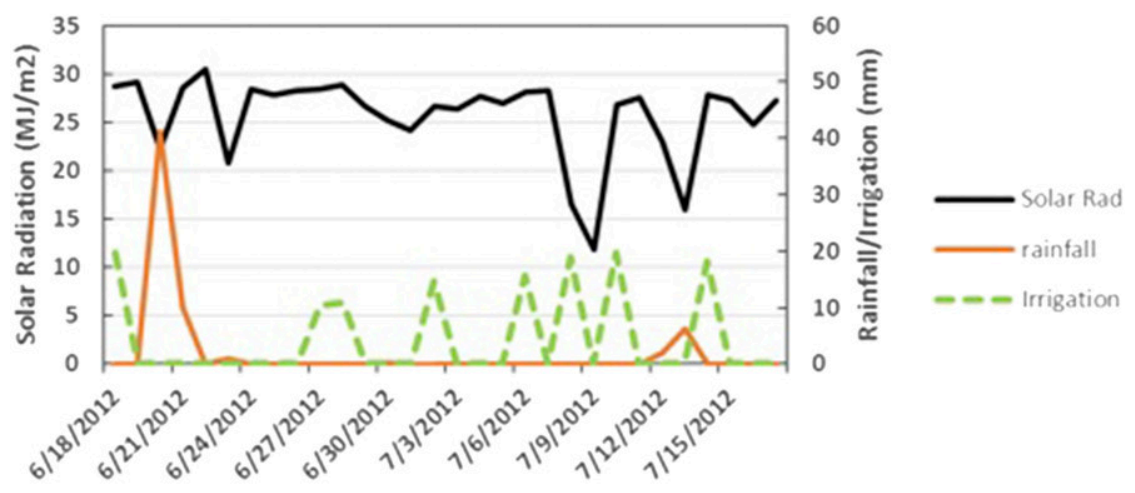

\section{Solar Radiation, Rainfall/Irrigation \\ VT Fungicide July 8}

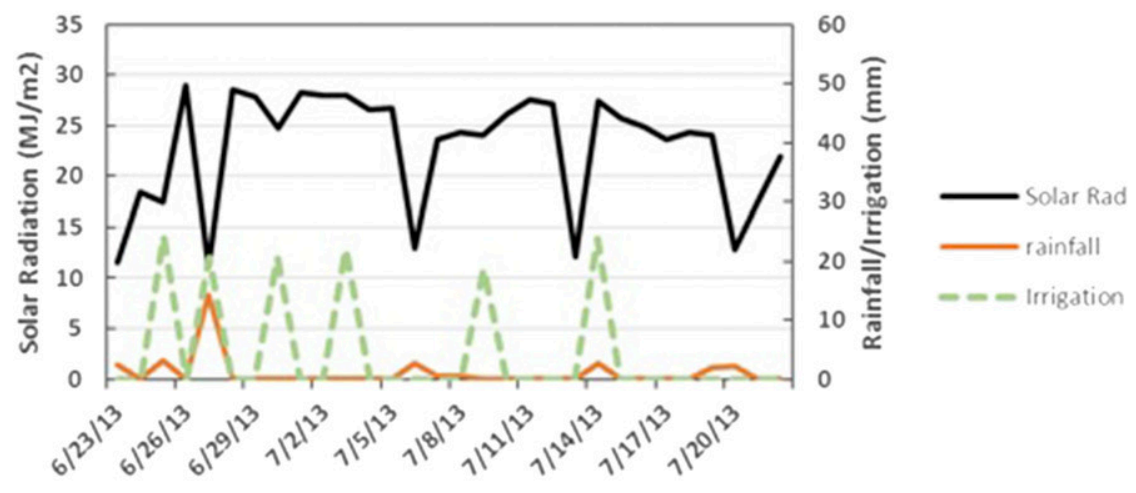

\section{Solar Radiation and Rainfall/Irrigation \\ VT Fungicide July 1}

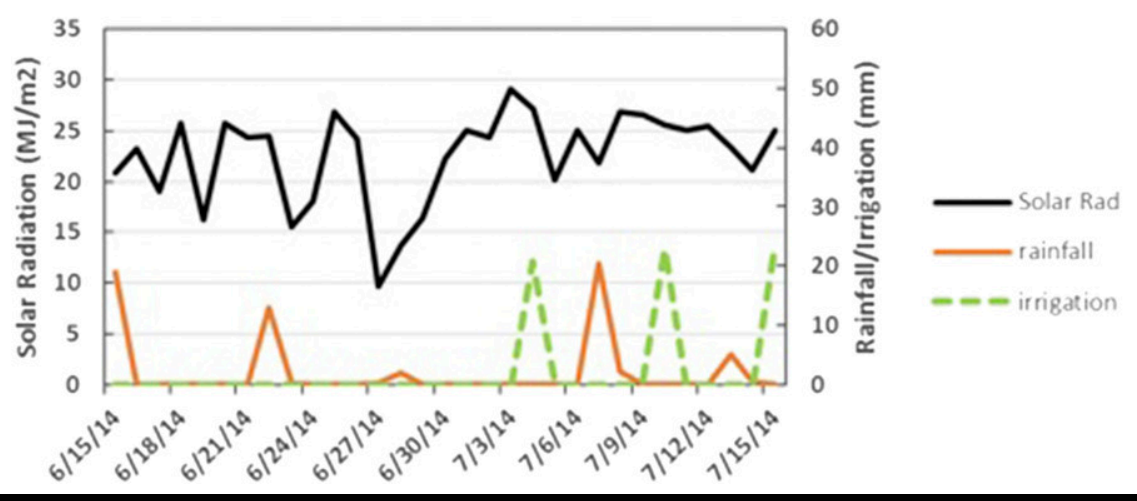

FIGURE 4

Rainfall, solar radiation, and irrigation in years without top dieback of corn at Kansas River Valley Experiment Field. Kansas State University Weather Data Library, 2012, 2013, and 2014

a positive return on investment for the fungicide application if the conditions warrant the application of a fungicide.

\section{Acknowledgments}

We want to thank Marty Johnson for assistance in conducting this study at NWRC. The fungicides and partial funding were provided by BASF Corp., Bayer CropScience, DuPont Crop Protection, FMC, and Helm Ag.

Contribution no. 16-271-J from the Kansas Agricultural Experiment Station.

\section{Literature Cited}

Abendroth, L. J., Elmore R. W., Boyer, M. J, Marlay, S. K. 2011. Corn Growth and Development. Coop. Ext. Publ. PMR 1009. Iowa State Univ., Ames.

Adee, E. A., Paul, L. E., Nafziger, E. N., and Bollero, G. 2005. Yield loss to corn hybrids to incremental defoliation. Crop Manage.

Bergstrom, G. C., and Nicholson, R. L. 1999. The biology of corn anthracnose. Plant Dis. 83:596-608. 
Jirak-Peterson, J. C., and Esker, P. D. 2011. Tillage, crop rotation, and hybrid effects on residue and corn anthracnose occurrence in Wisconsin. Plant Dis. 95:601-610.

Mueller, D., and Wise, K. 2012. Corn Disease Loss Estimates From the United States and Ontario, Canada-2012. Coop. Ext. Publ. BP-96-12-W. Purdue Univ., West Lafayette, IN. http://fyi.uwex.edu/fieldcroppathology/files/2014/ 01/BP-96-12-W.pdf.

Munkvold, G. P. 2002. Anthracnose top dieback is back. Integrated Crop Management News. Paper 1699. Iowa State Univ., Ames, IA. http://lib.dr. iastate.edu/cropnews/1699.

National Climate Data Center. 2016. http://www1.ncdc.noaa.gov/pub/orders/ IPS/

Robertson, A. 2007. Top dieback in corn: Is anthracnose the cause? Integrated Crop Management News. IC-498. Iowa State Univ., Ames, IA. http://www. ipm.iastate.edu/ipm/icm/2007/9-10/topdieback.html.
Robertson, A. E., Peckinovsky, K., and Liu, L. 2010. Effect of foliar fungicides on anthracnose top dieback, and frost injury of corn in Iowa, 2009. Plant Dis. Manage. Rep. 4:FC087.

Rogers, D. H., and Alam, M. 2008. KanSched2: An ET-based Irrigation Scheduling Tool. Res. and Ext. Publ. EP-129 revised. Kansas State Univ., Manhattan, KS.

Weather Data Library. 2016. Kansas State University. http://mesonet.k-state. edu/weather/historical/

Wise, K. 2010. Diseases of corn: Gray leaf spot. Coop. Ext. Publ. BP-56-W. Purdue Univ., West Lafayette, IN. https://www.extension.purdue.edu/extmedia/bp/bp-56-w.pdf

Wise, K. 2015. Fungicide efficacy for control of corn diseases. Coop. Ext. Publ. BP-160-W. Purdue Univ., West Lafayette, IN. https://www.extension.purdue. edu/extmedia/bp/bp-160-w.pdf

Wise, K., and Mueller, D. 2011. Are fungicides no longer just for fungi? An analysis of foliar fungicide use in corn. APS Feature http://dx.doi.org/ 10.1094/APSnetFeature-2011-0531. 